\title{
Space Syntax w strukturze komunikacyjnej dzielnicy Kośminek w Lublinie
}

\author{
Wojciech Kocki, Bartlomiej Kwiatkowski \\ Katedra Architektury, Urbanistyki i Planowania Przestrzennego, \\ Wydziat Budownictwa i Architektury, Politechnika Lubelska, \\ e-mail: w.kocki@pollub.pl,e-mail:b.kwiat@pollub.pl
}

Streszczenie: Układy urbanistyczne miast są jednymi z najbardziej złożonych struktur zaprojektowanych, wykonanych oraz użytkowanych przez człowieka, Stopień ich skomplikowania pod względem komunikacyjnym i łatwość przemieszczania się po nich jest zależna od wielu czynników i może być mierzona w różny sposób. Jednym z narzędzi parametrycznych umożliwiających badanie takich struktur jest metoda Space Syntax utworzona przez zespół naukowców z Bartlett University College London pod opieką Bill Hillier oraz Juliene Hanson. Do analizy wybrano fragment miasta Lublina położony pomiędzy ul. Męczenników Majdanka i ul. Władysława Kunickiego - dzielnicę Kośminek. Wykonano mapę osiową (ang. axial map) wybranego obszaru i poddano ją analizom przeprowadzonym przy użyciu programu Depthmap v. 0.3b. Współczynniki jakimi posłużono się aby poznać cechy układu urbanistycznego to współczynnik łączności (ang. Connectivity) i integralności (ang. Integration HH). Analizowany obszar i utworzone mapy osiowe podzielono na dwa etapy różniące się ilością uwzględnionych ulic pod względem ich przeznaczenia. Pierwszym etapem było utworzenie mapy osiowej z uwzględnieniem dostępnych ulic, drugim etapem było dodanie do istniejącej mapy wjazdów na posesje, dróg prywatnych oraz obszarów z ograniczeniami dla ruchu samochodowego. Wygenerowane zależności ukazane w formie schematów oraz zestawienia współczynników w diagramach rozproszenia posłużyły do odnalezienia problemów komunikacyjnych wybranego fragmentu. Metoda obliczeniowa Space Syntax umożliwia określenie wzajemnych powiązań przestrzeni pomiędzy obiektami kubaturowymi. Metoda ta jest stosowana nie tylko dla układów urbanistycznych ale również dla analiz rzutów budynków i wzajemnej korelacji ich pomieszczeń. Formułowane wnioski na temat organizacji danej struktury są zależne od synergii wielu współczynników wykorzystywanych dla jej określenia. Poprzez analizę diagramów rozproszenia pomiędzy zmiennymi Integration HH i Connectivity określono brak spójności przestrzeni w centrum wybranego obszaru, szczególnie ul. Długiej. Metoda Space Syntax jest stale rozwijana i ulepszana aby uzyskiwać coraz dokładniejsze wyniki a jej stosowanie i wykorzystywanie do analiz urbanistycznych może przyczynić się do rozwiązywania problemów komunikacyjnych w miastach.

Słowa kluczowe: urbanistyka, Lublin, komunikacja, architektura, space syntax.

\section{Wprowadzenie}

Analizowany obszar miasta Lublina położony jest w jego południowo wschodniej części. Wschodni fragment należy do Dzielnicy Kośminek a tereny położone po zachodniej stronie przy rzece Czerniejówce należą do Dzielnicy Dziesiątej. Wybrany układ urbanistyczny ograniczony jest dwoma głównymi ulicami: Drogą Męczenników Majdanka oraz ulicą Władysława Kunickiego (Rys. 1). Połączenie pomiędzy nimi zapewnia ulica Krańco- 
wa oraz Dywizjonu 303. Zabudowa jaka występuje na tym fragmencie miasta to w większości zabudowa mieszkaniowa jednorodzinna. Innymi formami są obiekty zabudowy mieszkaniowej wielorodzinnej oraz obiekty użyteczności publicznej tj. obiekty oświaty, szpital, kościół oraz zakład energetyczny. Komunikację północno południową zapewniają dwie ulice Wspólna oraz Długa, które nie są bezpośrednio połączone z zewnętrznymi ulicami obszaru. Komunikację wschodnio zachodnią układu tworzą ulice: Pawia, Lotnicza, Krańcowa, Dywizjonu 303, Sulisławicka oraz Wilcza.

Analiza komunikacyjna wybranego obszaru miasta jest kontynuacją badań nad jakością wzajemnych powiązań komunikacyjnych miasta Lublina.

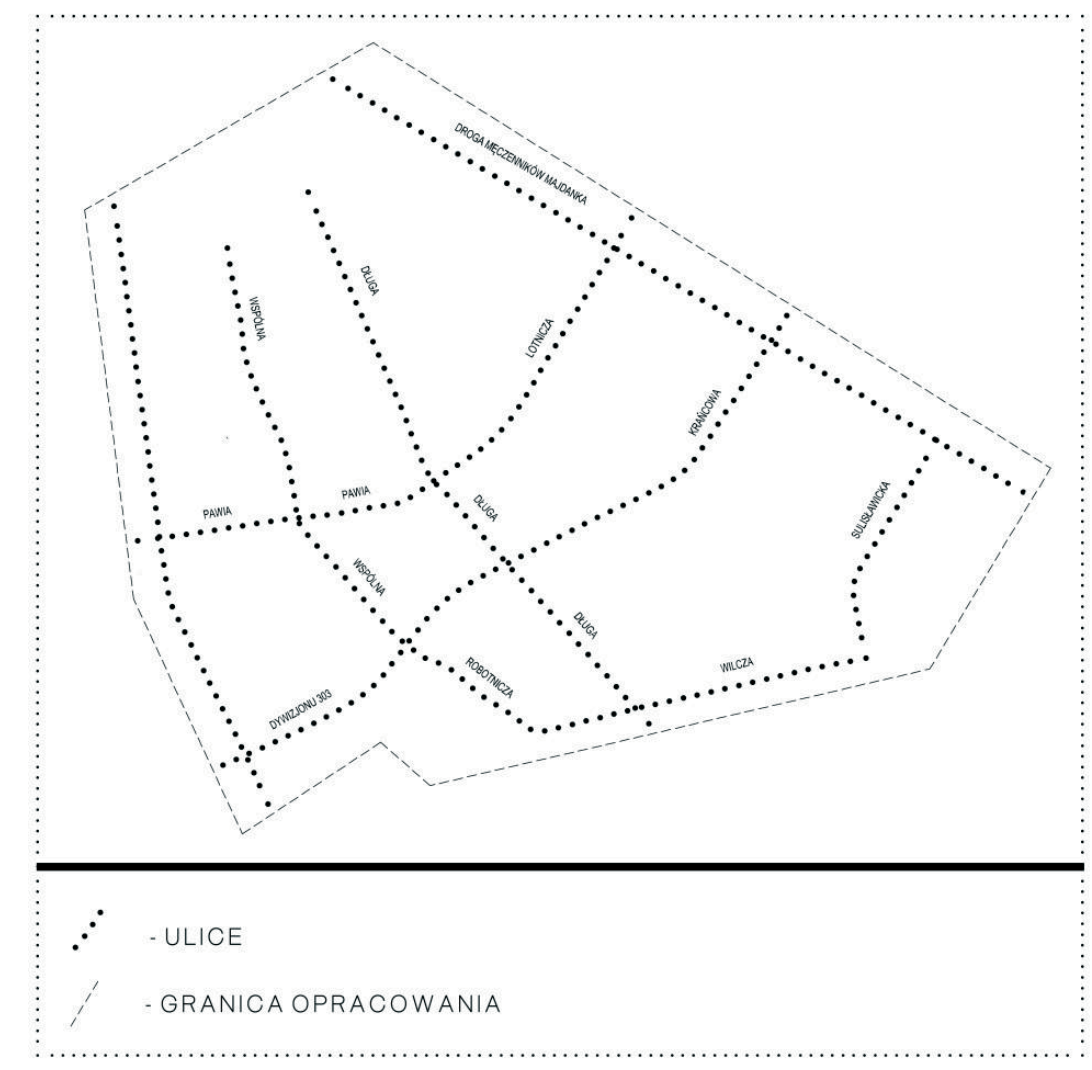

Rys. 1. Granica analizowanego obszaru miasta Lublina

\section{Space Syntax. Opis metodologii i zastosowanie}

Struktura komunikacyjna miasta jest od wielu lat jednym z głównych elementów badanych przez wielu naukowców. Wzajemne powiązania ulic struktur miejskich są uzależnione od czynników związanych z natężeniem ruchu, lokalizacji danej ulicy, funkcji, przeznaczenia (ilość obiektów użyteczności publicznej), jej charakteru zależnego od grupy użytkowników. Powiązania pomiędzy fizyczną przestrzenią w mieście i jej charakterem mogą wynikać z niematerialnych czynników socjologiczno psychologicznych [1 ss.86-88] tj. tworzenia się różnych form życia zbiorowego jak i procesów i zmian w nim zachodzących mających wpływ pośrednio na jakość przestrzeni w mieście. Jednym $\mathrm{z}$ takich czynników jest wzajemna dostępność oraz powiązanie wizualne przestrzeni ulic. Jeżeli ulica jest dobrze zintegrowana 
w układzie miejskim i łatwo dostępna zarówno dla pieszych jak i komunikacji samochodowej, taka przestrzeń jest często użytkowana i posiada większy potencjał rozwojowy tj. powstawania obiektów użyteczności publicznej jak i terenów przestrzeni publicznych. Możliwości związane z rozwojem przestrzeni publicznych mają wpływ na zmniejszenie chaosu przestrzennego, [1 ss.86-88] identyfikację miejsca, zwiększenie poczucia przynależności terytorialnej, poczucia wolności i swobody wyboru zachowań.

Metoda analizy Space Syntax została wprowadzona przez zespół naukowców z Bartlett University College London na przełomie lat siedemdziesiątych i osiemdziesiątych XX wieku, prowadzony przez jego głównych autorów Bill Hillier oraz Julienne Hanson.

\section{Struktura komunikacyjna miasta Lublina - Space Syntax}

\subsection{Zakres opracowania}

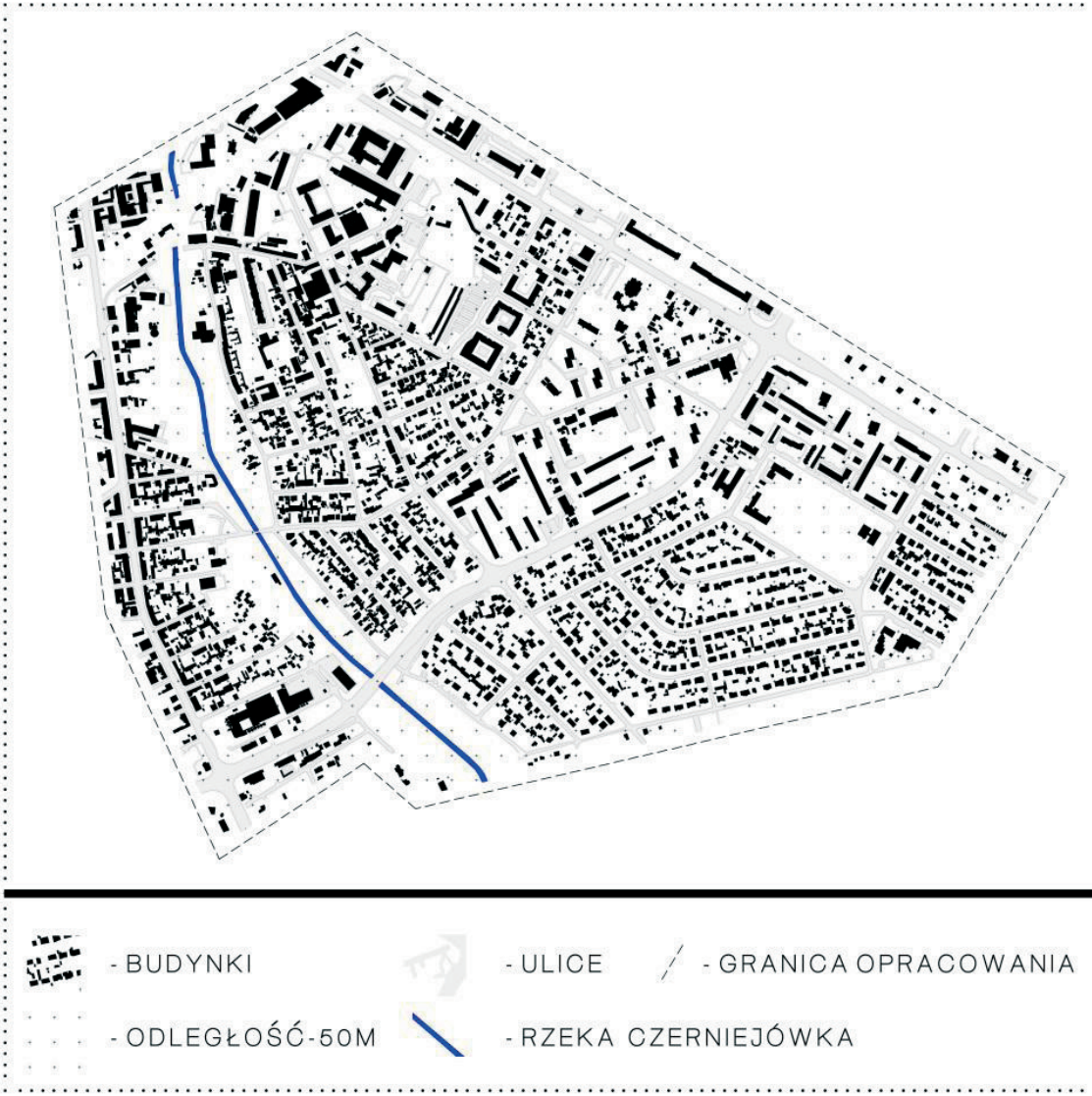

Rys. 2. Synteza struktury komunikacyjnej dzielnicy Lublina - Kośminek z zaznaczeniem zabudowy analizowanego obszaru

Analiza struktury zabudowy wybranego obszaru została ukazana na Rysunku 2, na którym dodatkowo uwzględniono układ komunikacyjny oraz rzekę Czerniejówkę, wzdłuż której położone są tereny zielone przestrzeni publicznych oraz tereny ogródków działkowych. Podział funkcjonalny zabudowy jest zauważalny poprzez skalę obiektów, w central- 
nej części analizowanego obszaru wyraźnie zaznacza się zabudowa jednorodzinna mieszkaniowa. Przy Drodze Męczenników Majdanka występuje bardziej zróżnicowana zabudowa o większej kubaturze tj. zabudowa mieszkaniowa wielorodzinna oraz użyteczności publicznej.

Metoda Space Syntax związana jest z poszukiwaniem wzajemnych powiązań przestrzeni (przestrzenie ulic, terenów zielonych itp.) położonych pomiędzy budynkami. $\mathrm{Na}$ rysunku 3 ukazano w sposób syntetyczny kolorem czarnym tą przestrzeń, która została poddana analizie. Największa ilość otwartej i niezabudowanej przestrzeni występuje wzdłuż rzeki Czerniejówki oraz wzdłuż Drogi Męczenników Majdanka.

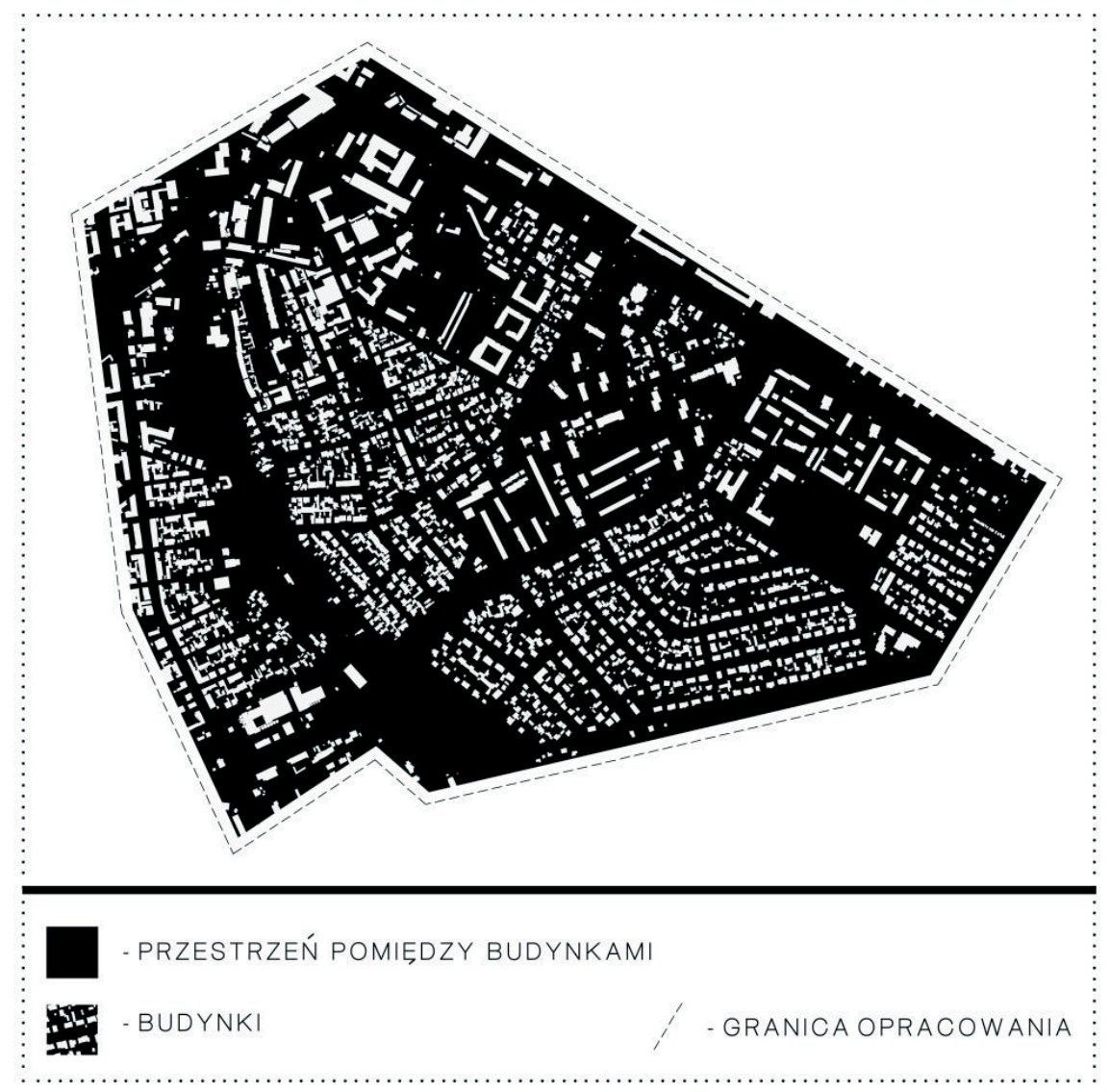

Rys. 3. Synteza przestrzeni pomiędzy budynkami

W Lublinie mieszka 343598 mieszkańców [2] i jest to jedno z największych miast Polski wschodniej. We współczesnych miastach procesy i zjawiska związane z ich rozwojem zachodzą bardzo dynamicznie i związane są ze strefą min. kulturową, przestrzenną oraz ekonomiczną. ,...średnie miasta to złożone organizmy...” [1 ss.120-122] współdziałające z najbliższymi mniejszymi miastami, które z czasem stają się ich dzielnicami ze względu na coraz mocniejsze ich powiązanie pod względem komunikacyjnym jak i społecznym. Wśród czynników wpływających na rozwój metropolii, najważniejsze z nich to rozwój terytorialny, demograficzny oraz społeczno-ekonomiczny. Wzrost poziomu tych czynników jest naturalnym procesem towarzyszącym urbanizacji, ewolucji oraz rozwojowi 
gospodarczemu. Aby stworzyć dogodne warunki życia mieszkańcom rozwijających się miast, zachować tożsamość miejsca, przynależność do grupy społecznej, bezpieczeństwo, identyfikację miejsca oraz zachować skalę przestrzeni od najbliższej, prywatnej znajdującej się w miejscu zamieszkania, poprzez przestrzeń codziennego poruszania się aż do publicznej przestrzeni całego miasta, istotnym elementem $\mathrm{w}$ ich kształtowaniu jest posługiwanie się narzędziami mogącymi ukazać przewidywany rozwój miasta oraz wpływ ingerencji urbanistycznych na cały jego układ.

\subsection{Model badawczy}

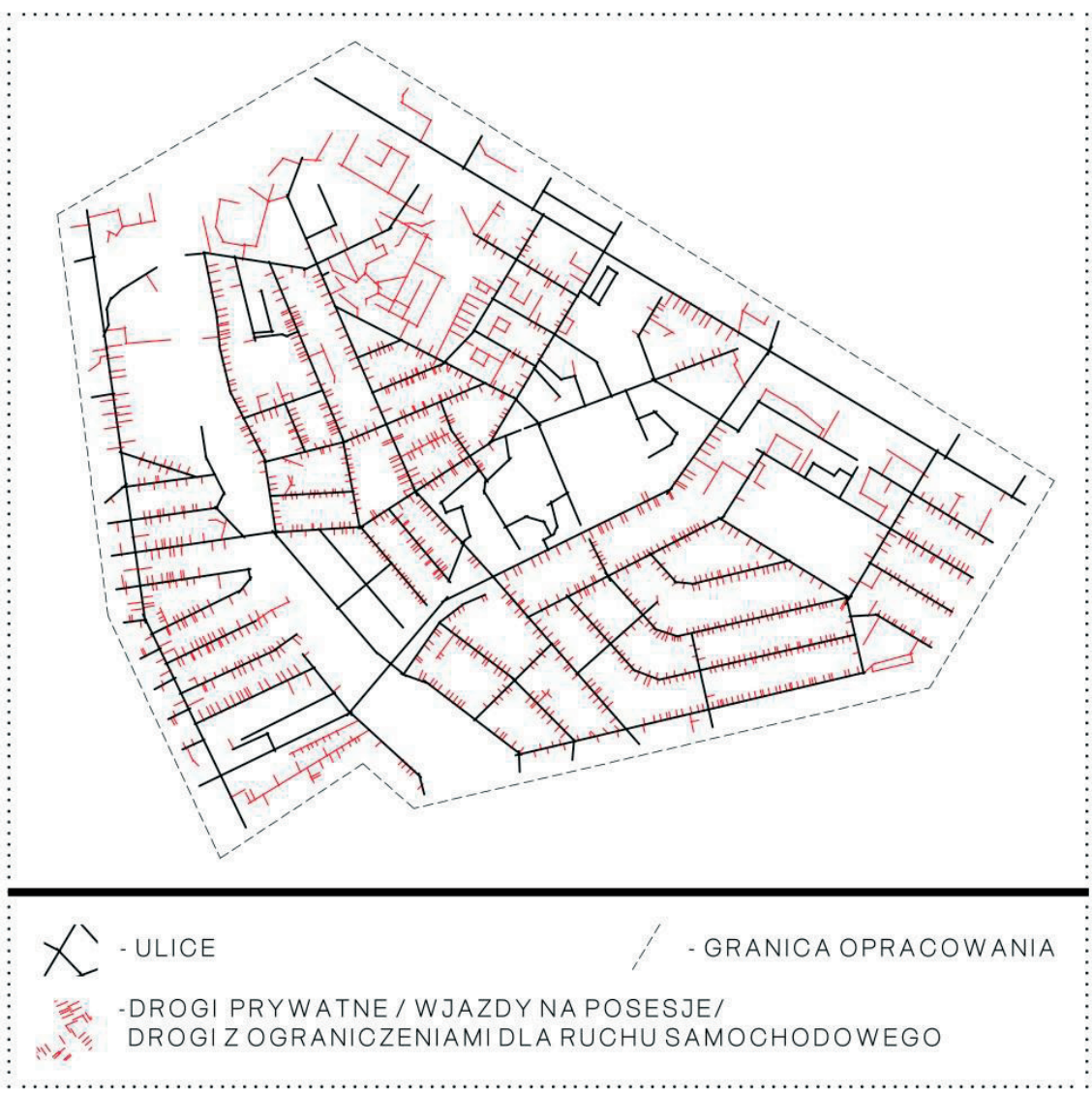

Rys. 4. Model połączeń ulic oraz dróg prywatnych, wjazdów na posesje oraz dróg z ograniczeniami dla ruchu samochodowego mapa osiowa (ang. axial map)

Wykonanie analizy space syntax w programie Depthmap v. 3.0b wymaga przygotowania mapy osiowej (ang. axial map), która zawiera połączenia przestrzeni ulic. W analizowanym obszarze wykonano dwie analizy z uwzględnieniem podziału na dwie warstwy komunikacyjne. Pierwsza są to ulice o swobodnym dostępie dla ruchu samochodowego kolor czarny, druga warstwa to również ulice o swobodnym dostępie dla ruchu samochodowego ale połączone z wjazdami na prywatne posesje oraz drogami prywatnymi. Zróżnicowanie to wynika z odmiennego natężenia ruchu względem przeznaczenia ulic a każde z połączeń może mieć znaczący wpływ na wyniki badań. Model poddano analizie pod 
względem dwóch współczynników dostępnych w programie Depthmap v. 3.0b Integration HH oraz Connectivity. [3 s. 25] Bill Hillier w swojej książce Space is the machine opisuje zasadę parametru Integration HH jako współczynnik względem, którego badany jest stopień integracji danej przestrzeni w odniesieniu do całego układu tzn. im więcej kierunków (przestrzeni) dzieli wybraną od centralnej części całości układu tym mniej jest ona zintegrowana. Parametr Connectivity odnosi się do ilości połączeń danej przestrzeni z innymi.

Przykładem zastosowania tej metody dla utworzenia nowych powiązań przestrzeni w mieście, przeznaczonej dla pieszych jest propozycja w Ljubljanie wykonana przez Space Syntax Ltd. Analiza wykazuje wpływ dodania do istniejącej struktury miejskiej kolejnego ośrodka urbanistycznego o potencjale utworzenia centralnej struktury łączącej i integrującej $\mathrm{w}$ istniejącym układzie dwa ośrodki znacznie oddalone od siebie.

\subsection{Analiza Integration $\mathrm{HH}$}

Wyniki analizy Integration HH ukazują wysoki stopień zintegrowania ulicy Długiej w odniesieniu do całego układu. Wynika to z wielu czynników min. centralnego położenia tej ulicy oraz jej długości. Duże znaczenie na wyniki badań to brak połączenia tej ulicy z zewnętrznym układem od strony północnej oraz niewielkie zintegrowanie od strony południowej. Brak połączenia w północnej części pośrednio wynika z istniejącej tam linii kolejowej. Analiza warstwy ulic o swobodnym dostępie uwzględniając wjazdy na posesje oraz drogi prywatne również ukazuje problem z integracją ulicy Długiej w jej północnej części. Rysunek 7 ukazuje jak znacząca jest ulica Długa w całym układzie komunikacyjnym wybranego obszaru.

\subsection{Analiza Connectivity}

Wyniki analizy Connectivity nie są jednoznaczne. W pierwszym wariancie analizowanych jedynie ulic o swobodnym dostępie dla ruchu samochodowego możemy zauważyć ulicę Lotniczą jako najbardziej wyróżniającą się pod względem ilości połączeń na tle całej struktury. Rysunek 8 ukazujący analizę z uwzględnieniem wjazdów na posesje oraz dróg prywatnych również wskazuje na ulicę Lotniczą ale dodatkowo jeszcze na północny fragment ulicy Długiej. Współczynnik Connectivity dla analizowanego obszaru szczególnie wyraźnie wskazuje na brak jednoznacznego zróżnicowania na przestrzenie najbardziej ze sobą połączone aż do najmniej zintegrowanych. Większość ulic w tej strukturze posiada tą samą wartość współczynnika. Najbardziej obciążonymi ulicami pod względem ilości wjazdów i dróg dodatkowych jest część południowa układu z ulicą Wilczą. 


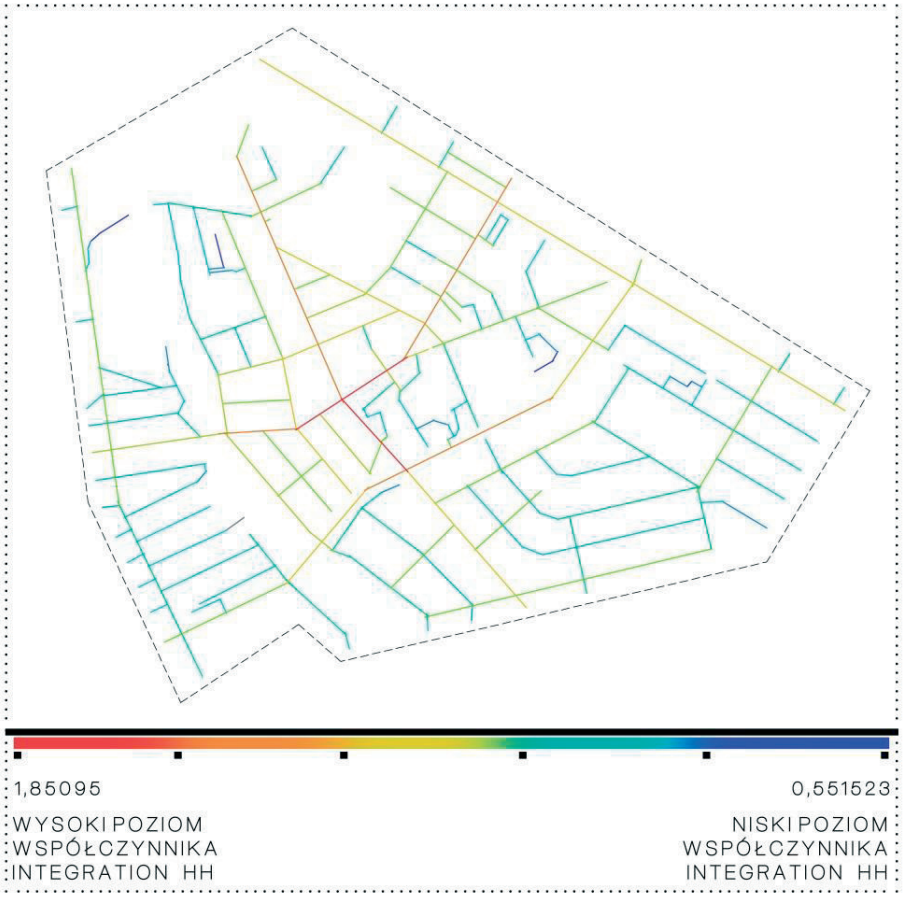

Rys. 5. Wynik analizy Integration $H H$ programu Depthmap v. $0.3 \mathrm{~b}$ - ulice

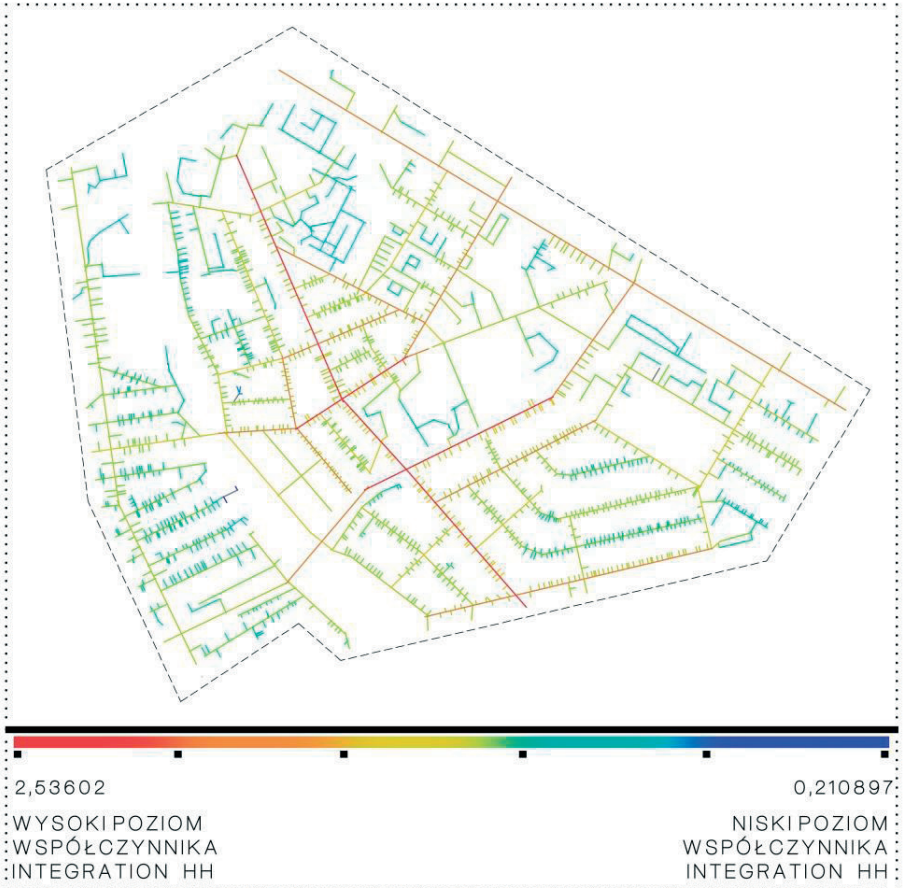

Rys. 6. Wynik analizy Integration $H H$ programu Depthmap v. $0.3 \mathrm{~b}$ - ulice z uwzględnieniem wjazdów na posesje, dróg prywatnych i dróg z ograniczeniami dla ruchu samochodowego 


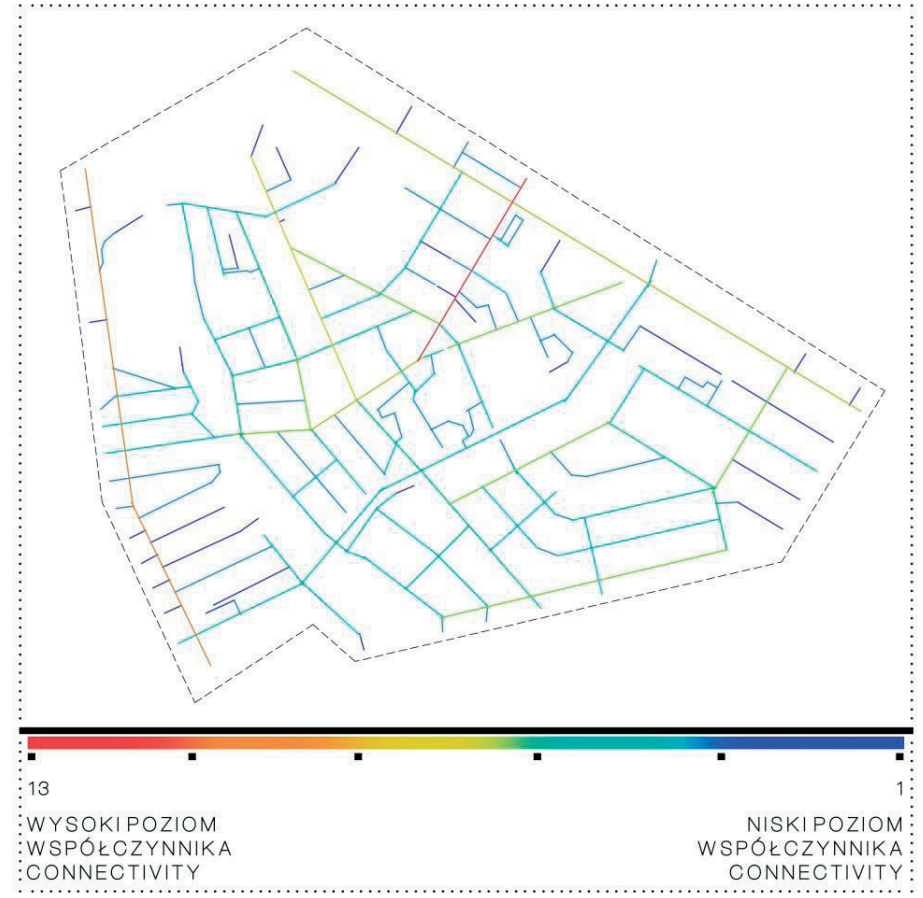

Rys. 7. Wynik analizy Connectivity programu Depthmap v. $0.3 \mathrm{~b}$ - ulice

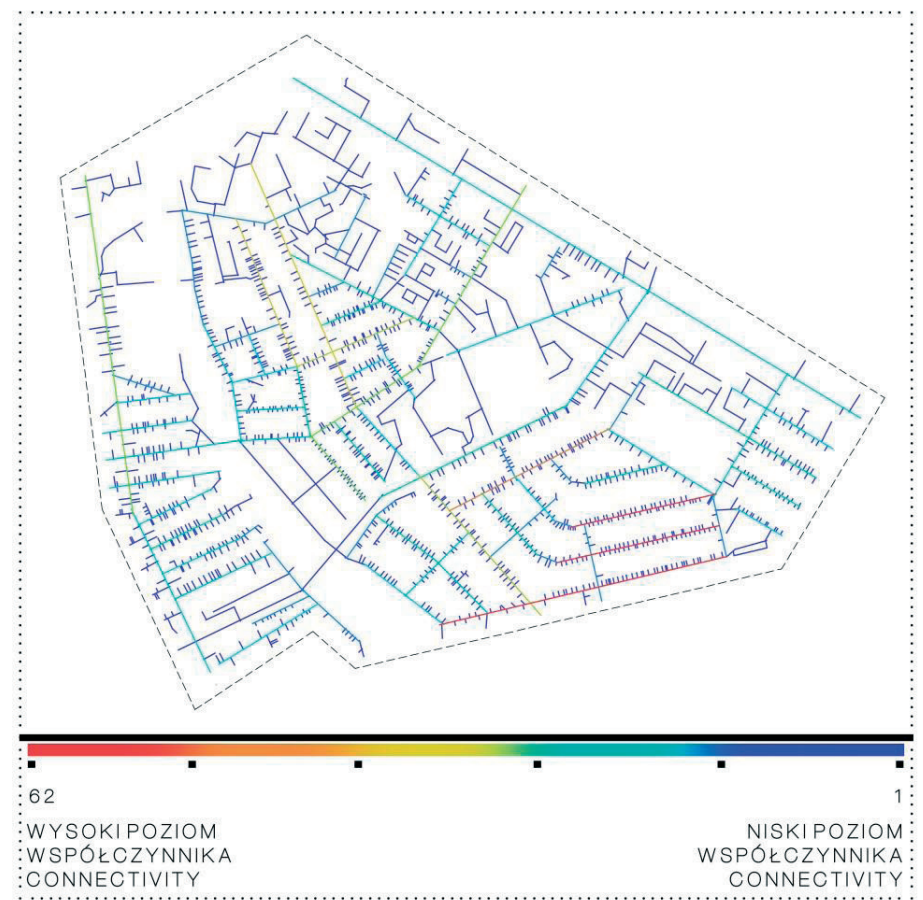

Rys. 8. Wynik analizy Connectivity programu Depthmap v. $0.3 \mathrm{~b}$ - ulice z uwzględnieniem wjazdów na posesje, dróg prywatnych i dróg z ograniczeniami dla ruchu samochodowego 


\section{Wnioski}

Współcześnie metody numeryczne wspomagające projektowanie są niezastąpionym narzędziem umożliwiającym w krótkim czasie poznanie bardzo dużej ilości istotnych informacji. Początkiem był rok 1961 i przełomowe wydarzenie jakiego dokonał (doktorant wydziału elektrycznego MIT) Ivan Sutherland, który stworzył możliwość komunikowania się pomiędzy komputerem a projektantem przez Sketchpad [1 ss.239-250].

Procedury parametryczne wykorzystywane w oprogramowaniu umożliwiającym tworzenie nowych i innowacyjnych struktur lub analiz mogą być źródłem niezbędnych informacji, które w procesie projektowym mogą wpłynąć znacznie na podejmowane decyzje. W projektowaniu urbanistycznym dotyczącym jednej z najbardziej skomplikowanej i złożonej struktury jaką jest miasto wykorzystanie oprogramowania umożliwiającego wprowadzenie mnogiej ilości danych wydaje się być niezbędne aby prawidłowo podejmować decyzje projektowe ingerujące pośrednio w całą strukturę miejską.

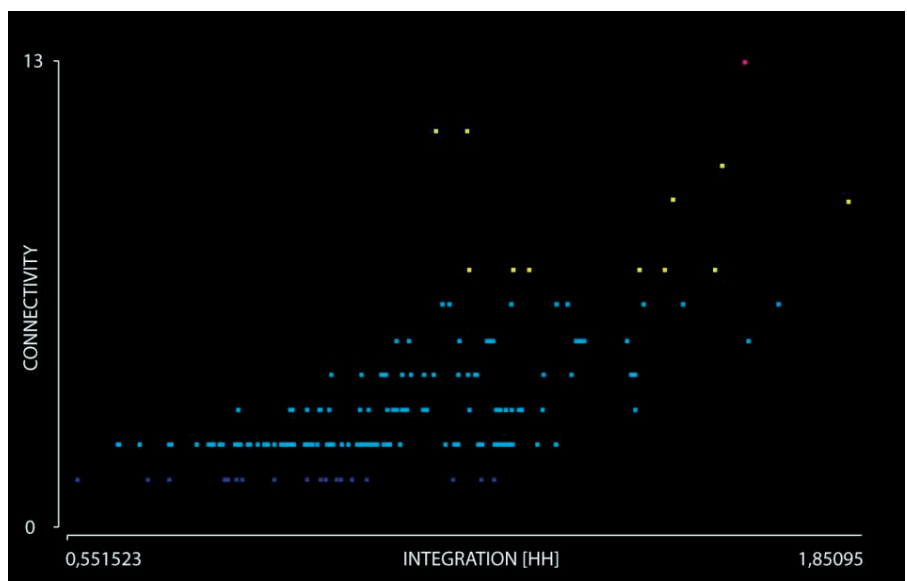

Rys. 9. Diagram rozproszenia (ang. Scattergram) współczynników Integration HH i Connectivity programu Depthmap v. $0.3 \mathrm{~b}-$ ulice

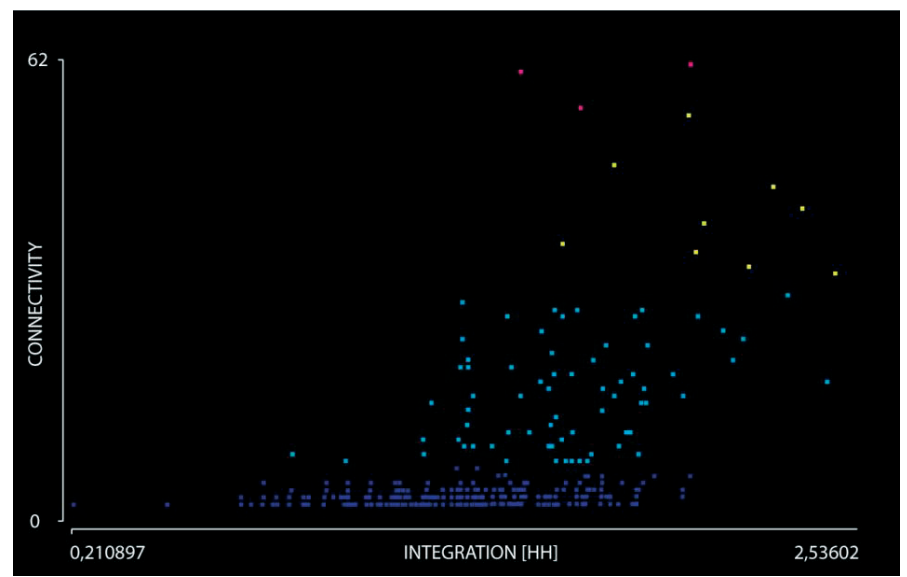

Rys. 10. Diagram rozproszenia (ang. Scattergram) współczynników Integration HH i Connectivity programu Depthmap v. $0.3 \mathrm{~b}$ - ulice wraz z wjazdami na posesje, drogami prywatnymi oraz drogami $\mathrm{z}$ ograniczeniami dla ruchu samochodowego 
Ilość, jakość oraz sposób wykorzystania przestrzeni publicznej zależy od ilości osób mieszkających lub pracujących w jej pobliżu. [5] Jeżeli przestrzeń publiczna usytuowana jest w miejscu gdzie jej dostępność dla mieszkańców zależy od kilku minut spaceru to jej wykorzystanie będzie intensywne a taka lokalizacji sprawia, że chętniej i częściej będą ją wykorzystywać stali mieszkańcy. Problemem może być znaczna odległość do takich przestrzeni, która już wymaga dojazdu samochodem lub środkiem komunikacji miejskiej.

Zależności pomiędzy odległością i korelacją przestrzeni prywatnych oraz publicznych można analizować dzięki metodzie space syntax. W odniesieniu do analizowanego obszaru dzielnicy Kośminek pod względem integralności oraz łączności jej struktury komunikacyjnej można stwierdzić, że jej centralna część wzdłuż ulicy Długiej jest głównym elementem łączącym ten obszar i elementem z brakiem integracji w całej strukturze. Diagramy rozproszenia powstałe w programie Depthmap v. 3.0b na podstawie współczynników Integration HH oraz Connectivity (Rysunek 9 oraz 10) wyraźnie ukazują problemy dotyczące współzależności pomiędzy tymi dwoma współczynnikami. Poprawna zasada ich powiązania ukazuje proporcjonalny wzrost współczynnika Connectivity do współczynnika Integration HH. W analizowanym obszarze najwięcej rozbieżności można zauważyć w przestrzeniach ulic o średnich współczynnikach, przestrzenie o minimalnych oraz maksymalnych wartościach są bardziej zbliżone do prawidłowych wyników.

Powyższe wyniki analiz są wstępem do badań nad układem struktury komunikacyjnej miasta Lublina w odniesieniu do parametrycznej teorii modelu zależności pomiędzy przestrzeniami - Space Syntax. Rezultaty dalszych badań mogą przyczynić się do polepszenia jakości połączeń komunikacyjnych w miastach. Założenia Space Syntax są ciągle ulepszane i rozwijane w taki sposób aby umożliwić uzyskanie coraz dokładniejszych wyników.

\section{Literatura}

1. Lorens P., Martyniuk-Pęczek J. Miasto, Metropolia, Region, Zarzadzanie rozwojem przestrzennym miast. wydawnictwo Urbanista, Gdańsk 2010. ss. 86-88, ss. 120-122, ss. 239250.

2. Główny Urząd Statystyczny, Warszawa 2014, s. 176.

3. Hillier B. Space is The Machine. University of Cambridge, 2007, s. 25.

4. Czerkawer-Yamu C., Voigt A. Strategic Planning and Design with Space Syntax, Respecting Fragile Places. 29th eCAADe Conference Proceedings, 125-133. eCAADe: Conferences., 2011, s. 131.

5. Austin G. Green Infrastructure for Landscape Planning, Integrating human and natural systems. Glasgow 2014., ss. 142-147. 


\title{
Space Syntax in communication structure of Lublin's district - Kośminek
}

\author{
Wojciech Kocki, Bartlomiej Kwiatkowski \\ Department of Architecture and Urban Planning, \\ Lublin University of Technology, \\ e-mail:w.kocki@pollub.pl,e-mail:b.kwiat@pollub.pl
}

\begin{abstract}
Urban structures are one of the most complicated forms designed ad used by people. Degree of their complexity due to internal communication and simplicity of movement from one point to another depends on various of factors and may be measured by various tools. One of that tool is Space Syntax method mainly based on measuring integration and connectivity in particular structure. This method was used to research a communication system in one of the Lublin's district - Kośminek. Conclusions are coming down to specify streets in urban grid which have the highest factor of connectivity and integration value and comparison them in scattergrams.
\end{abstract}

Keywords: urban planning, Lublin, communication, architecture, space syntax. 
